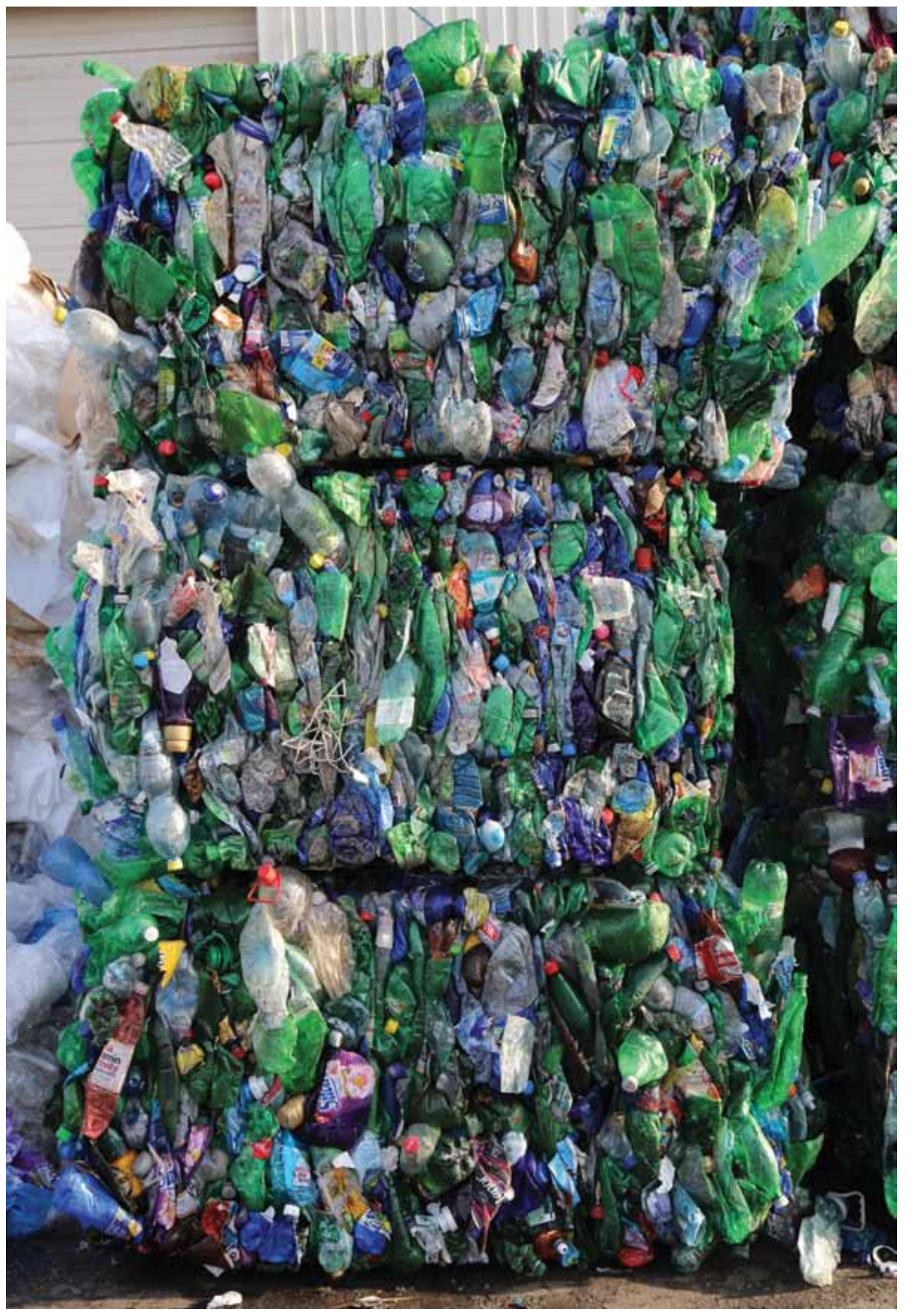

SI. 1. Balirane separacije otpada u pogonu za reciklažu EKO-FLOR PLUS d.o.o (fotografirao: D. Gamulin). 


\section{Izložiti otpad u muzeju}

\section{Damir Gamulin, Antunn Sevšek}

DOI: $10.17234 / 9789531757232-17$

Konceptualnom odlukom autorice izložbe postavile su razmatranje teme ponovne upotrebe $u$ arheologiji u neočekivanu domenu proizvodnih procesa i karakteristika samih skupina materijala. Istovremeno, ove povijesne prakse reflektirane su kroz promišljanje našeg nesigurnog odnosa prema vrijednosti nusprodukata suvremenog društva. Ovako postavljen zadatak osmišljavanja postava izložbe bio je više nego dovoljno intrigantan razlog za ulazak u projekt. Ova inicijalna dvostruka promjena rakursa u kojoj su izloženi predmeti svedeni na puku sirovinu, odnosno dovedeni u blizak interpretativni odnos sa gotovo bezvrijednim suvremenim otpatcima iskorištena je kao neposredna osnova likovnosti i narativnosti postava.

Izraženi i namjerno doslovni kontrast između vrijednih artefakata izloženih u reprezentativnom izložbenom prostoru povremenih izložbi i suvremenih separacija materijala iz procesa recikliranja poslužio nam je za izgrađivanje čitavog postava. Temeljen na niz jednostavnih projektantskih gesti, on je krajnje reduciran, ne bi li se maksimalno naglasila intencija izložbe i postigla željena razina narativnosti i didaktičnosti.

Izložbene su prostorije tako preparirane kontinuiranim oplošjem od recikliranog tekstila s ciljem izmještanja prostora izložbe iz zahtjevnog i ekspresivnog povijesnog interijera muzeja i time usmjeravanja pažnje posjetitelja na centralno postavljene izloške.

Svi artefakti, muzejski opisi i predmetne legende predstavljeni su u različitim permutacijama jednog te istog drvenog elementa, bilo u svojstvu rudimentarnih vitrina, jednostavnih postamenata ili pak vertikalno postavljenih elemenata koji su nosili tekstualne opise pojedinih izložbenih cjelina. Unutar tih izlagačkih elemenata organizirani su narativni sljedovi arheoloških fragmenata, muzejskih opisa i ilustracija procesa ponovne upotrebe odabranih materijala. Princip njihovog slaganja kao cjelovitih likovnih kompozicija u kojima su artefakti promatrani jednakovrijedni pripadajućim tekstualnim opisima omogućio je ukidanje pojedinačnih i naknadno apliciranih legendi te dodatno istaknuo namjeru autorica za jezgrovitim komuniciranjem osnovnih principa i značenja pojedinih skupina materijala. 


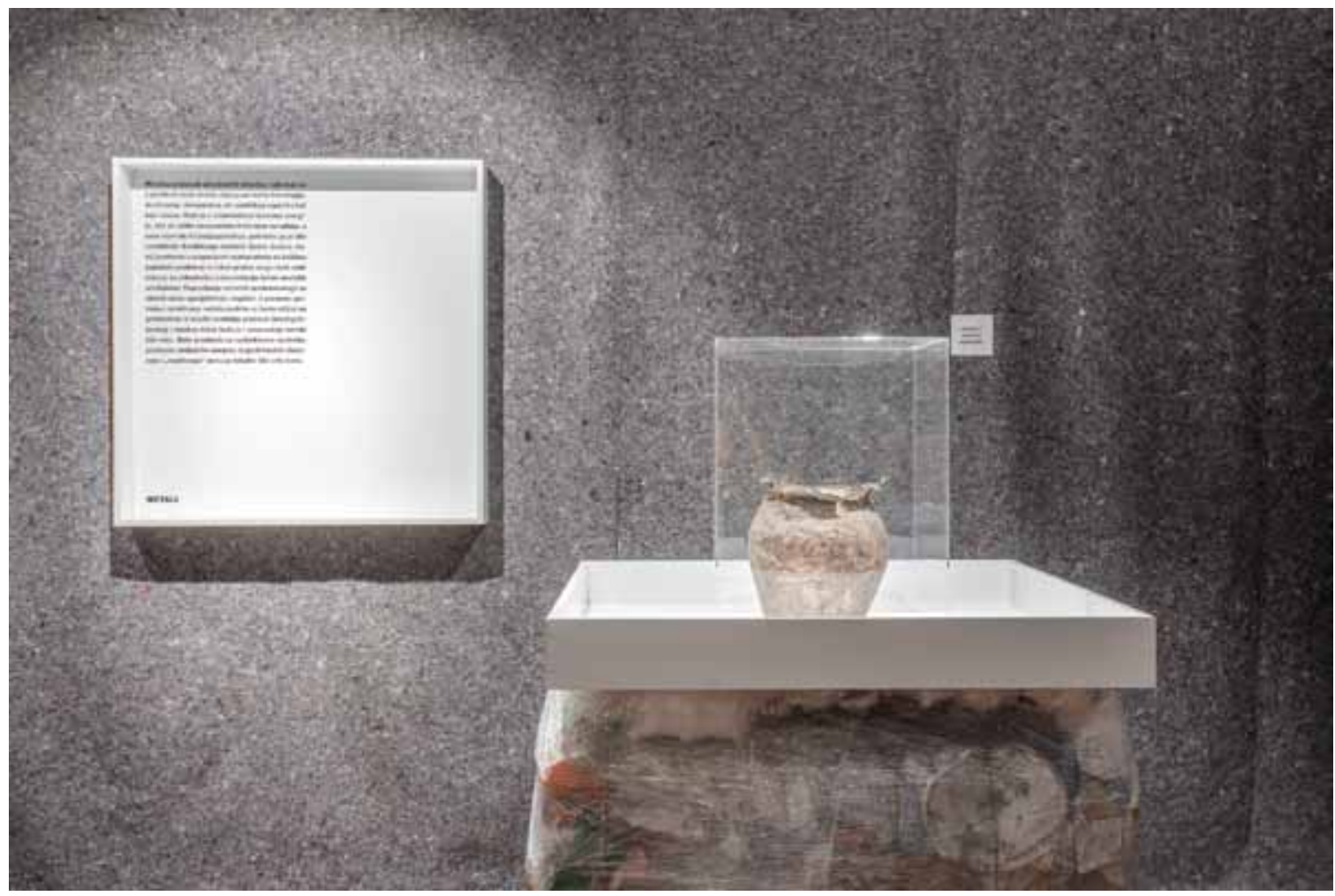

Slijedeći element postava predstavljale su bale odabranih sirovina iz pogona za reciklažu prenesene u muzej. Postavljene u pravilna polja koja su ispunila prostor izložbe iskorištene su kao osnovni postamenti izložaka. Reducirane i delikatne izložbene vitrine tako su kontrastirane s gruboćom i neuglednosću zatečenih postamenata. Ova doslovna gesta postavljanja otpada u muzej, odnosno postavljanja "vrijednih" artefakata na "bezvrijedne" postamente izravan je odgovor na zahtjev autorskog tima da postav doprinese diskurzivnom potencijalu izložbe. Istovremeno, uniformirano pokrivanje bala vizualno iskontroliranim plitkim vitrinama omogućilo je njihovo 'pripitomljavanje' nužno kontekstu formalnog izložbenog prostora te izbjegavanje grotesknog i banalnog učinka koji bi pažnju odvukao od sadržaja same izložbe.

Tema ponovne upotrebe prostora, predstavljena je pak kroz uvođenje predimenzioniranog fotografskog uvećanja jednog od ključnih primjera ove prakse, približavajući posjetitelja stvarnom mjerilu graditeljske geste, $\mathrm{u}$ jasnom kontrastu $\mathrm{s}$ filigranskim fragmentima na ostatku izložbe.

Zaključno, nastavljajući ispitivanje potencijala doslovnog korištenja koncepta recikliranja u procesu izrade grafičkog i prostornog rješenja identiteta i postava izložbe, plakati za izložbu izvedeni su kao serija ponovno upotrebljenih plakata prethodnih izložbi na koje su u nekoliko slojeva tiskane osnovne informacije o novoj izložbi.

Izveden unutar ograničenih financijskih mogućnosti no uz kontinuiran i konstruktivni dijalog svih uključenih u proces rada, a čime je postignut komplementaran odnos između sadržaja i oblikovanja njegovog predstavljanja, nadamo se da je ovaj postav dao posjetiteljima i iskustveni poticaj promišljanju ove vrijedne teme. 
SI. 3. Detalj izložbenog postava (fotografirao: D. Žižić).
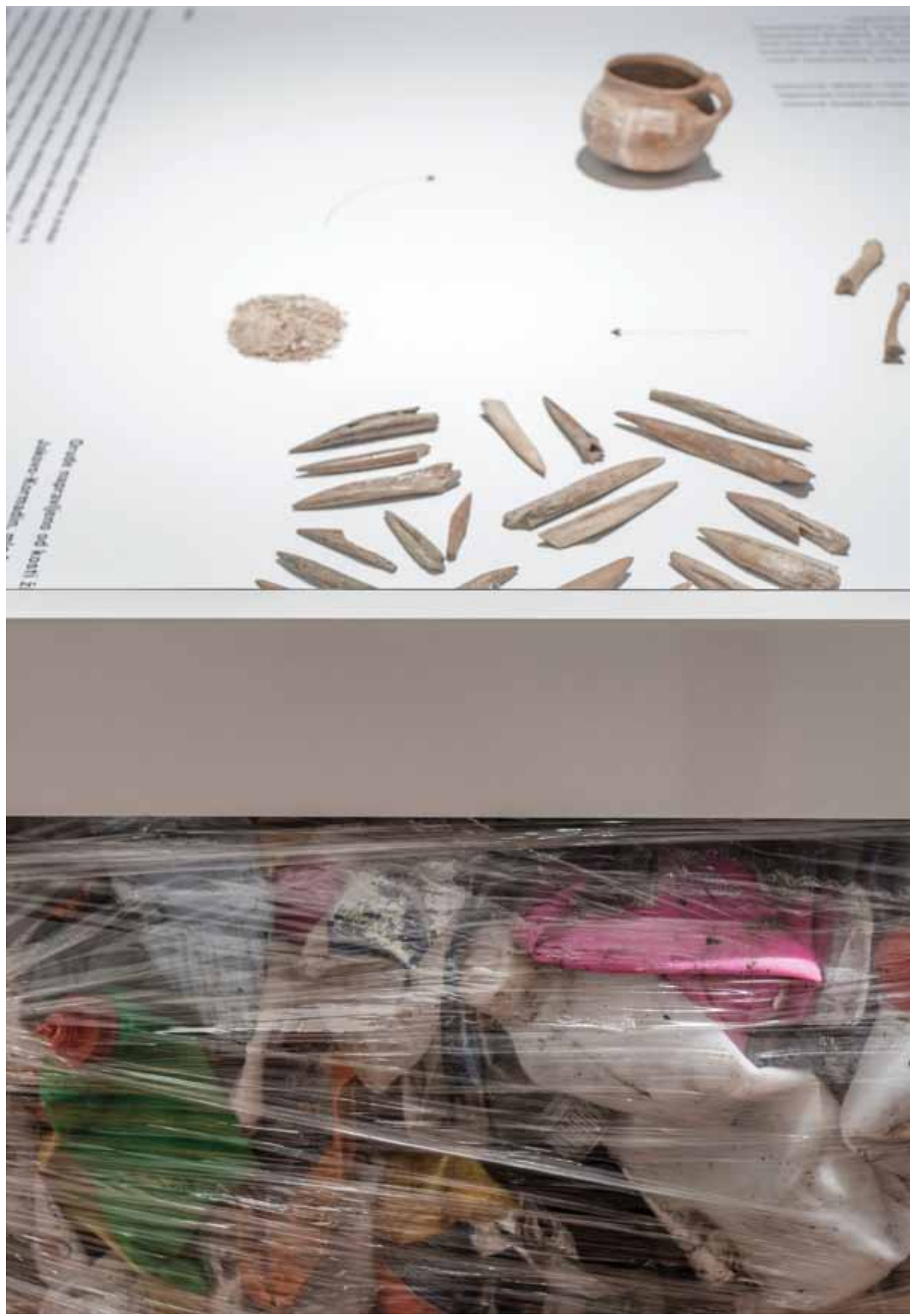